\author{
Nermina Črdalija ${ }^{1,3}$, Ivana Jovović ${ }^{2}$, Nedžad Leko ${ }^{1}$ \\ ${ }^{1}$ Filozofski fakultet u Sarajevu, ${ }^{2}$ University of Connecticut, Department of Linguistics, \\ ${ }^{3}$ Centre for Language and Cognition Groningen (CLCG), University of Groningen \\ nermina.cordalija@ff.unsa.ba,n.cordalija@rug.nl,ivana.jovovic@uconn.edu, nedzad.leko@ff.unsa.ba
}

\title{
Postverbal conjoined subjects and closest conjunct agreement in Bosnian/Croatian/Serbian: an experimental study 1
}

\begin{abstract}
In some previous experimental work on agreement strategies in South Slavic languages, it was demonstrated that the closest conjunct agreement (CCA) is the only available strategy for agreement with conjoined noun phrases in postverbal contexts. However, the examples that are claimed to be a result of CCA could potentially be analyzed as a clausal ellipsis (CE). The CE analysis was argued for by Aoun, Benmamoun and Sportiche (1994). In their approach based on examples from three dialects of Arabic, the postverbal linear agreement was claimed to be a result of CE, not of CCA. Thus, they predicted the semanticindependence of two coordinated events. However, this claim is difficult to defend if a specific type of predicates is taken into account - the so-called collective predicates. Therefore, we designed a sentence-picture matching experiment with collective verbs and postverbal subjects with speakers of Bosnian/Croatian/Serbian (BCS) to test whether the postverbal linear agreement was a result of phrasal coordination or $\mathrm{CE}$. The study managed to show that CCA is not a result of $C E$, but a distinct agreement strategy.
\end{abstract}

\section{Introduction}

In previous experimental work on agreement strategies in Bosnian/ Croatian/ Serbian (BCS)2 (see Čordalija et al. 2016), we demonstrated that BCS, like Slove-

1 Our thanks are due to two anonymous reviewers whose comments have helped us to revise the original draft. The remaining shortcomings and errors are, of course, our responsibility. We are also grateful to Jana Willer-Gold for her support and comments.

2 We use the name Bosnian/Croatian/Serbian (rather than Central South Slavic, which is an option offered by a reviewer) for the language we investigate in this paper. The participants of our experiment were from Sarajevo, where this term has official status (although it is generally not used in Croatia and is considered to be politically incorrect, as pointed out by a reviewer). However, a reviewer points out that there are significant differences between the Štokavian-based standard languages spoken in Bosnia and Herzegovina, Croatia, and Serbia, and some of them affect agreement patterns, e.g. the construction Kolege su rekle (rather than 
nian (see Marušič, Nevins, and Badecker 2015), has three distinct strategies for subject-predicate agreement when the subject consists of conjoined noun phrases (with a hierarchical structure, as in (1) below)3: (i) default agreement (DA) - that is, agreement with the maximal projection, a Boolean Phrase (\&P); (ii) closest conjunct agreement (CCA) - agreement with the conjunct that is closest to the participle (that is, agreement with the last conjunct $\left(\mathrm{NP}_{2}\right)$ in subject preverbal order (SV order), or agreement with the first conjunct $\left(\mathrm{NP}_{1}\right)$ in subject postverbal order (VS order); (iii) highest conjunct agreement (HCA) - agreement with the conjunct that is hierarchically the highest $\left(\mathrm{NP}_{1}\right)^{4}$.

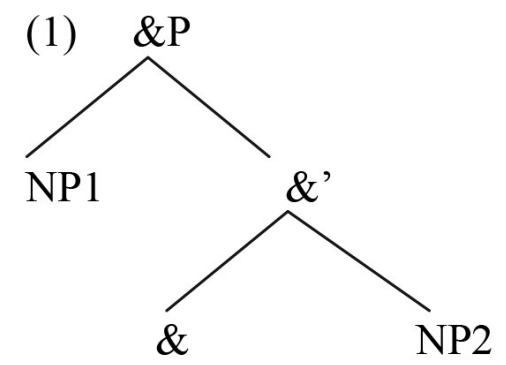

Each of the conjuncts has its own categorical and phi features (number and gender). So the predicate may agree with features of one of the conjuncts, or the predicate may manifest a default agreement, that is the agreement with the features of the maximal projection. A default number feature of the maximal projection is always plural in BCS, even when both conjuncts are singular, whereas default gender feature is masculine. We adopt here proposal by Doron (2000) that the conjunction, that is \&P in our system, does not have the morphosyntactic specification for the feature number. However, Badecker (2007) points out that languages may

rekli) is seldom heard in Standard Croatian, whereas it is quite common in Serbian.

3 The structure in (1) represents a standardly assumed representation/ derivation of coordinate expressions. However, it should be pointed out that some other proposals found in the literature would lead to radically different predictions. For example, Mitrović and Sauerland (2016) propose that DP-coordination involves at least two morphemes (see also Mitrović 2014; Mitrović and Sauerland 2014) which they denote as $\mu$ and J. They propose that there exist both a "nominal" e-type and "verbal" or "clausal" t-type junctor. They assume that $\mu$ is of a semantic type that combines with a single type $e$ argument, while $\mathrm{J}$ is of a type that combines two type $t$ arguments. In most languages, only one of these two morphemes is pronounced in NP conjunction. Consequently, there exist two types of conjunctions and languages: those with an overt $e$-type conjunction, for example, Japanese mo, and those with overt $t$-type conjunction, for example, English and. Thus, their proposal predicts that $e$-type and $t$-type conjunction morphemes should be different, though phonologically not necessarily distinct, morphemes across languages. In contrast to the traditional analysis of coordination structure, as in (i) (which we adopt in this paper), Mitrovic and Sauerland (2016) offer the $\mu$-structural analysis of coordination structure, as in (ii) ( where $\mathrm{J}^{0}=\&^{0}$ ):

(i) $\left[\mathrm{BP}_{1} \mathrm{CO}_{1}\left[\mathrm{CO}_{2}\right]\right]$

(ii) $\left[{ }_{\mathrm{JP}}\left[{ }_{\mu \mathrm{P} 1} \mu^{0}{ }_{1} \mathrm{CO}_{1}\right]\left[_{\mathrm{J}^{\prime}} \mathrm{J} 0\left[_{\mu \mathrm{P} 2} \mu_{2}^{0} \mathrm{CO}_{2}\right]\right]\right]$

Crucially, on the type of analysis given in (ii), the external conjunct never c-commands the internal conjunct/ coordinand (co). The question is whether a $\mu$-structure with the Junction super-structure is always projected.

4 In this paper, we opted for the terminology highest conjunct agreement and closest conjunct agreement. Instead, the terms like first and last conjunct agreement could be used, which pertain to linear order alone. A reviewer points out that in postverbal conjunct configurations, the highest available goal of the agreement is the maximal category \&P, not the external conjunct. The latter is linearly closest. 
differ concerning the number specification of \&P. So in BCS, agreement with a conjoined subject always results in the plural, regardless of the position of the subject or the number specification of individual conjuncts.

We also label here the coordinated phrase as \&P. However, Chomsky (2013) has a different proposal - if $Z$ and $W$ are coordinated, then their underlying structure is given in (a). Such a structure, according to Chomsky, captures the semantic symmetry of coordination. To label $\beta$, one of the conjuncts must raise. If $Z$ is the conjunct that raises, then it gives the structure in $(b)$ :
(a) $[\alpha \operatorname{Conj}[\beta Z W]]$
(b) $[\gamma Z[\alpha \operatorname{Conj}[\beta Z \mathrm{ZW}]]$

Now $\beta$ receives thelabel of W. As far as $\gamma$ is concerned, Chomsky claims that it is unlabelable because it is a $\{\mathrm{XP}, \mathrm{YP}\}$ structure. Nevertheless, it needs a label. Chomsky claims that the label is not Conj but rather the label of $Z$, typically shared with W. If the coordinated expressions are NPs, then $\gamma$ is an NP. It follows that Conj and the construction $\alpha$ that it heads are not available as a label so that $\gamma$ receives the label of $Z$. In other words, the maximal projection of a coordinated nominal phrase should be NP rather than \&P.

In order to test the three agreement strategies, a controlled experimental study of the morphosyntactic agreement between conjoined subjects and participles in BCS was conducted. The results obtained in this experimental study proved that the CCA and DA are major strategies for preverbal conjoined subjects. On the other hand, CCA is the dominant agreement strategy in contexts with postverbal subjects (95\% of the examples). A drastic decrease in the number of examples of DA in contexts with postverbal subjects may be explained as a result of the fact that in VS order there is no conjunct phrase \& $\mathrm{P}$ c-commanding the goal5. Also, another factor contributes to this - namely, in VS order the closest conjunct is at the same time the highest conjunct. Therefore, we have two agreement strategies combined, CCA and HCA.

However, the examples of CCA in postverbal contexts could potentially be explained as a result of clausal ellipsis $(\mathrm{CE})^{6}$, as in (2):
(2) a. Uborbisu
se
sudarala
koplja i
sablje.
in battle AUX PRT collided ${ }_{N}$
'Spears and swords collided in the battle.' spears $_{N}$ and
swords $_{F}$
b. Uborbi su se sudarala koplja iuborbi suse sudarate sablje.

\footnotetext{
5 This statement relies on assuming coordination structure in (i) over the one in (ii) given in the footnote 2.

6 A reviewer points out that CE analysis is a Conjunction Reduction (CR) analysis which Schein (2017) most recently defended.
} 
This was claimed by Aoun, Benmamoun and Sportiche (1994). In their approach based on examples from three dialects of Arabic, the postverbal linear agreement is, in fact, a result of CE, not of CCA. Therefore, they predict the semantic independence of two coordinated events. ${ }^{7}$ However, this claim is difficult to defend if a specific type of predicates is taken into account, so-called collective predicates. ${ }^{8}$ This point was first taken by Munn (1999) who showed that with such predicates the intended two-event semantics will be preserved, but the agreement will be with the linearly closest conjunct. However, if the appropriate context is not provided, it may be difficult to control whether judgments on CCA with conjoined plurals and collective predicates reflect one-event or two-event readings of the predicates. Therefore, we designed a sentence-picture matching experiment with collective verbs and postverbal subjects. The experiment was aimed to test the claim that postverbal linear agreement is a result of phrasal coordination and not of clausal ellipsis. It was conducted at the University of Sarajevo with 30 participants, third-year students, all native speakers of BCS. ${ }^{9}$

By way of illustration, one picture depicted spears and swords colliding and was accompanied by the sentence given in (2a). If this sentence were a result of clausal coordination, as in (2b), then the interpretation of a sentence would be as of two colliding events, that is, spears colliding with spears, and swords colliding with swords. On the other hand, the phrasal coordination assumes that the interpretation of the sentence is such that spears collide with swords, that is, one colliding event. And that is exactly what is depicted in the picture. It means that sentences such as (2a) could not be matched with pictures that have a one-event reading (in this case it is a reading of spears colliding with swords) if such sentences were derived by a clausal ellipsis. On the other hand, with non-collective predicates, there should not be such a mismatch.

The experiment was designed in such a way that the participants in the experiment were given a sentence and accompanying picture and they had to determine whether a sentence matches a picture and to what degree (on a $0-100 \%$ scale). Thirty participants were tested. A 2x2 factorial design was employed, with collective predicates (collide-type verbs) and simple, non-collective predicates (display-type

$7 \quad$ As pointed out by a reviewer, a vP-level conjunction alone would predict this. World-level binding differences are additionally predicted on a $\mathrm{CE}$ analysis.

8 A reviewer points out that this follows from a $\mathrm{CE}$ analysis, but is not directly tied to the event distinctness mentioned in the previous sentence.

9 It should be pointed out that our paper was prepared for publication before a co-authored paper in which we participated, and which is about to appear in Syntax (see Arsenijevic et al. 2020). That paper, as well as our paper, is the outcome of a series of experiments which were designed and performed as a part of the international project Experimental morphosyntax of South Slavic (EMSS) involving Universities in Zagreb, Zadar, Novi Sad, Nis, Sarajevo, Zenica, and Nova Gorica, coordinated from the University College London and funded from the Leverhulme Trust. In this project, a method of parallel design of material was adopted and experimental procedures were performed in seven locations. The authors of this paper contributed to the design of experimental materials and the execution of experiments in Sarajevo. Nevins (2016) discussed preliminary cumulative results of the sentence-picture matching experiments performed in these seven experimental locations. 
verbs), eight of each, contrasting conjoined \&P subjects (e.g. spears and swords) with simple NPs (e.g. swords), yielding 32 experimental items and 32 fillers. We give a fuller description of the experiment in section 4 .

Examples of the conjoined \&P subjects with collective and non-collective verbs are given in (3):

\begin{tabular}{|c|c|c|c|c|c|}
\hline $\begin{array}{l}\text { a. Uborbisu } \\
\text { in battle AUX }\end{array}$ & $\begin{array}{l}\text { se } \\
\text { PRT }\end{array}$ & $\begin{array}{l}\text { sudarala } \\
\text { collided }_{N}\end{array}$ & $\begin{array}{ll}\text { koplja } & i \\
\text { spears }_{N} & \text { and }\end{array}$ & \multicolumn{2}{|c|}{$\begin{array}{l}\text { sablje. } \\
\text { swords }_{F}\end{array}$} \\
\hline $\begin{array}{l}\text { b. Uprodavnici } \\
\text { in shop }\end{array}$ & $\begin{array}{l}\text { su } \\
\text { AUX }\end{array}$ & $\begin{array}{l}\text { izložena } \\
\text { displayed }_{N}\end{array}$ & $\begin{array}{l}\text { ogledala } \\
\text { mirrors }\end{array}$ & $\begin{array}{l}i \\
\text { and }\end{array}$ & $\begin{array}{l}\text { lampe. } \\
\text { lamps }\end{array}$ \\
\hline
\end{tabular}

The experiment demonstrated that there is a statistically significant difference between sentences depending on the type of verb used. Sentences containing collective verbs were rated lower than those with non-collective verbs. This difference could be potentially accounted for by the semantic complexity of collective predicates themselves. In other words, the difference does not have to be a result of the type of conjunction (clausal versus phrasal conjunction).

However, it turned out that there was no significant difference in ratings between sentences containing conjoined \&P subjects and simple NP subjects with collective verbs (collide-type verbs). It means that sentences with conjoined \&P subjects and collective predicates are not derived using clausal ellipsis. Otherwise, such sentences would be rated considerably lower than all others, because the picture with which such sentences were paired would be incompatible with the interpretation which assumes two-event semantics. And such reading would be inevitable if such sentences underlyingly have a biclausal structure. Therefore, we conclude that sentences with conjoined \&P subjects cannot be a result of elided clausal coordination.

\section{Previous accounts of predicate agreement with conjoined subjects}

The phenomenon of the subject-predicate agreement has been intensively studied, particularly in the Slavic languages. Various proposals were offered, such as establishing agreement hierarchies taking into account types of agreement controllers and targets (Corbett 1983a, b). Considerable attention has been paid to predicate agreement with coordinated subject noun phrases, including postverbal subjects, a type of agreement that we will discuss in our paper. These studies can contribute to a wider discussion about the role of agreement in grammar (see, for example, Benmamoun, Bhatia, and Polinsky 2010, Munn 1999, and Bhatt and Walkow 2013), as well as to experimental investigations of attraction phenomena 
(as discussed, for example, in Bock and Miller 1991, Franck et al. 2006, Franck, Frauenfelder, and Rizzi 2007, and Franck 2011).

Investigations of agreement phenomena in Slavic languages are dominated by two approaches. One is exclusively syntactic, in which the syntactic analysis of agreement phenomena is based on native-speaker intuitions or theoretical predictions, taken in Bošković 2009, 2010, Franks and Willer-Gold 2014, and Puškar and Murphy 2015. The second may be characterized as multicomponent, or "distributed," on the assumption that in addition to the syntactic component, agreement processing also involves another, postsyntactic component, where at PF linear order is available for purposes of Agree. This approach is taken by Marušič, Nevins, and Saksida (2007) and Marušič, Nevins, and Badecker (2015).

Bošković (2009) offers a uniform account of first- and last-conjunct agreement based on the operation Agree. According to Bošković, with postverbal subjects, participles in Serbo-Croatian always exhibit first-conjunct agreement (for gender), and with preverbal subjects, only last-conjunct agreement (also for gender) is exhibited. His basic assumption is that agreement is handled exclusively in the syntax by the operation Agree. Bošković predicts (or at least provides judgments to the effect that) HCA is disallowed in preverbal-subject contexts (although he does not state it explicitly).

Marušič, Nevins, and Badecker (2015) present three agreement strategies in Slovenian based on five experimental studies. The agreement can target one of three feature-bearing controllers: Conj1, Conj2, or \&P. The 'closesness' of the controller can be measured in several ways: hierarchically, the highest conjunct in the specifier of a BoolP $(=\& \mathrm{P})$ in the specifier of a verb phrase is closer to the verbal head than the second conjunct, but nonetheless, speakers may opt for the second conjunct, which is linearly closer. By contrast, choosing the BoolP $(=\& \mathrm{P})$ head itself may be the closest element of the relevant type, namely the head of the entire phrase. They emphasize that the choice of an agreement controller thereby must negotiate these distinct types of the locality. Marušič, Nevins, and Badecker assume that the operation Agree is carried out in two steps: Agree-Link and AgreeCopy. Agree-Link always applies in narrow syntax, but Agree-Copy can apply either in the syntax or postsyntactically.

\section{Previous accounts of predicate agreement with postverbal conjoined subjects: Aoun, Benmamoun and Sportiche (1994); Munn (1999)}

Aoun, Benmamoun, and Sportiche (1994) discuss complex systems of agreement in three varieties of Arabic (Lebanese (LA), Moroccan (MA), and Standard Arabic (SA)). They claim that the agreement systems can be analyzed in terms of a structural relation between an agreeing head and its specifier (Spec-Head agreement). However, they point out that the subject-verb agreement involving conjoined subjects complicates the agreement system. The internal structure of the 
subject which is preverbal does not influence the pattern of agreement. However, the pattern is affected in the case of postverbal subjects. The authors show that in three varieties of Arabic a verb preceding a subject with conjoined NPs may agree as if the verb were followed by only the first member of the conjunction, which means that it can agree with the first conjunct. This may be illustrated with an example from MA:

(4) Mša umarwali.10

left $_{3 M S}$ Omar and Ali

'Omar and Ali left.'

Here the third person singular masculine form of the verb ( $m s ̌ a)$ is used in agreement with the features of the first conjunct (Umar).

When the conjoined subject is preverbal then only plural agreement of the verb (mšaw) is possible, as obvious from (6):

(6) a. umarwali mšaw/*mša.

OmarandAli left ${ }_{P} /$ left $_{3 M S}$

'Omar and Ali left.'

When the conjoined subject is postverbal, the verb may also agree with both conjuncts, so that in (7) from another dialect (LA), the plural form of the verb (raaho) agrees with plural features of the conjoined subject phrase:

(7) Raaho omarwali.

left $_{p} \quad$ Omar and Ali

'Omar and Alileft.'

The authors use the term partial agreement to designate those cases in which the verb agrees only with the first conjunct of a postverbal conjoined subject. In such cases, the first conjunct, and not the whole conjoined subject, is in a Spechead relationship with the verb. It means that the first conjunct is the subject. Aoun et al. claim that sentences of the form [V NP and NP ...] have the structure of coordinated clauses and not of coordinated NPs.

The authors offer arguments for clausal conjunction. They point out that if sentences with conjoined subjects represent a conjunction of NPs, then the subject of the clause should be able to behave like a plural subject semantically, even in those cases when the plural agreement is not required. On the other hand, if such sentences instantiate conjunction of clauses, then they contain two clauses underlyingly, each clause having a singular subject. Under this assumption, the subject

10 The phonetic representation of Arabic examples is simplified (i.e. not all phonetic symbols are used) since it is not crucial for the discussion. 
should not be able to behave as if it denotes a plurality. The authors claim that sentences in which the verb agrees with the first of the two conjoined NPs in postverbal position represent a conjunction of two propositions, not two NPs. ${ }^{11}$

To prove this, they consider examples with relative clauses that modify the two NPs forming a single constituent. In such cases, it is expected that the option of the verb agreeing with the first NP will not be available when such a verb precedes the conjoined NPs. In (8) the relative clause must restrict the two NPs because of the selectional properties of the verb 'meet' inside the relative clause, which requires a plural subject. It means that in (8) the two NPs (l-walad and l-muallim) must form a single constituent.

(8) Raaho/*Raah l-waladwl-muallim yalliltao uala-l-madrase. (LA) went $_{P} /$ went $_{3 M S}$ the-boy and the-teacher who met ${ }_{P}$ at-the-school 'The boy and the teacher who met went to school.'

Since the two NPs indeed form a single constituent in (8), the verb that precedes the conjoined subject cannot agree with the first NP conjunct so that the sentence with the third person singular masculine form of the verb (raah) in agreement with the first conjunct ( $($-walad) is ungrammatical.

As a consequence of their approach which assumes clausal analysis of postverbal conjoined subjects, the authors are treating an Arabic sentence in (9a) structurally identical to (9b) or (9c):

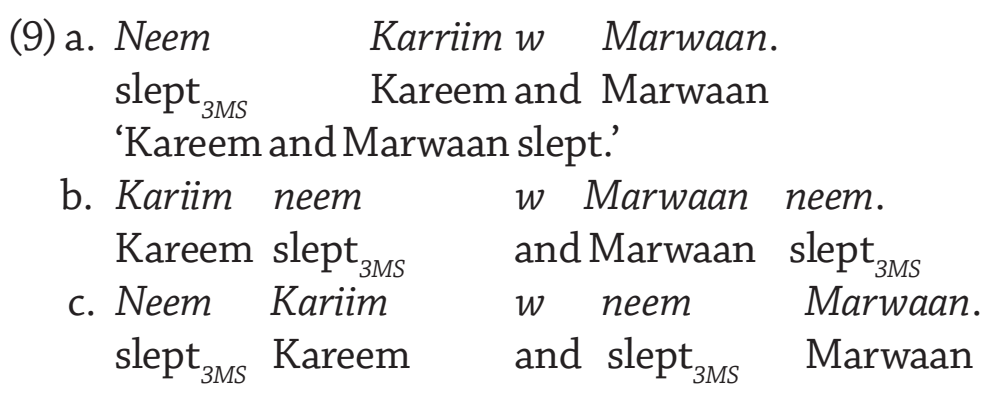

This approach accounts for the verbal agreement in (9a) - the fact that the verb (neem) agrees with only one conjunct and that it must be the first, and not the second conjunct.

Munn (1999) claims that Aoun, Benmamoun and Sportiche (1994) do not make a distinction between syntactic and semantic agreement, and therefore their explanation of the clausal source of first conjunct agreement in VS contexts in some

11 They discuss only the number agreement. We assume that certain properties of the agreement are universal and affect agreement in all categories. However, a reviewer points out that the assumption that gender agreement with the first conjunct in BCS (tested in our experiment) is essentially the same phenomenon as number agreement with conjoined subject in the varieties of Arabic does not have to be correct. It is possible, for example, as pointed out by a reviewer, that number agreement is sensitive to some semantic factors which do not play a role in gender agreement. 
varieties of Arabic (LA and MA) is empirically inadequate. However, he provides new examples from these dialects indicating that the first conjunct agreement is possible. Therefore, the clausal analysis must be ruled out.

Munn reviews the distinction between semantic and syntactic plurality. He points out that the independence of syntactic and semantic plurality can be demonstrated by the existence of collective nouns (e.g. group) that are semantically plural but syntactically singular, and the existence of pluralia tantum nouns (e.g. scissors) that are semantically singular but syntactically plural.

Munn also emphasizes that some predicates (e.g. meet in English) when used intransitively, require the semantic plurality of their subject. Therefore, such predicates can have either syntactically singular (e.g. group) or syntactically plural subjects (e.g. men). On the other hand, the syntactically plural but semantically singular nouns (e.g.scissors) cannot be subjects of such predicates. Somelexical elements (e.g., together and same/ different) are also in this category, requiring the subject to be semantically plural. However, there are some predicates (e.g. be similar) that require both syntactic and semantic plurality. Therefore, singular semantic plurals (e.g. group) and plural semantic singulars (e.g. scissors) cannot be subjects of such predicates.

Aoun et al. discuss some examples when the conjoined subject with the first conjunct agreement is not possible with those sentence elements that require plurality. However, Munn claims that they do not manage to show that semantic plurality licenses such sentence elements. For example, Aoun et al. show that the modifier sawa 'together' in LA can modify a conjoined preverbal subject, but not a conjoined postverbal subject with the first conjunct agreement. The sentence is grammatical only when the verb agrees with both conjuncts in the postverbal position.

However, Munn points out that the modifier sawa requires a syntactically plural antecedent (e.g. el rijal 'men'). This modifier is incompatible with a singular subject that is semantically plural (e.g. eljamaa 'the group'). It means that sawa requires both syntactic as well as a semantic plurality to be licensed. Therefore, he concludes that examples with sawa offered by Aoun et al. are not an appropriate test to prove that the first conjunct agreement is clausal.

Munn emphasizes that a similar situation occurs with reflexives and reciprocals. Aoun et al. give examples with pronominal reflexives (haalun 'themselves') and reciprocals (badun 'each other') pointing out that these elements require a plural antecedent. The postverbal conjoined subject may function as the antecedent for reflexives and reciprocals only when the verb agrees with the whole postverbal subject. On the other hand, such a subject cannot function as antecedent when the verb agrees only with the first conjunct. Munn points out that in this case Aoun et al. show that only syntactically plural antecedents may license plural reflexives. However, he concludes that their examples are not sufficient to show that the first conjunct agreement is not semantically plural. 
Aoun et al. also show that first conjunct agreement subjects cannot appear with intransitive verb ltaa 'meet' in LA. Therefore, when used intransitively, this verb cannot occur with a postverbal subject and have a singular agreement. Instead, the plural agreement must be used. However, Munn offers examples with a semantically plural noun as the subject (e.g. el-jama 'the group'), and in such cases, the verb ltaa 'meet' cannot take singular agreement. Only the plural agreement is possible, although the noun el-jamaa 'the group' can have the singular agreement with other verbs.

Therefore, Munn concludes that the fact that first conjunct agreement subjects cannot license elements such as sawa 'together', reflexives, and reciprocals is not sufficient to demonstrate that such subjects are not conjoined and therefore not semantic plurals. Such examples indicate that many sentence elements are sensitive to syntactic plurality. He points out that the examples given by Aoun et al. may be consistent with the clausal coordination analysis, but they are also consistent with a phrasal coordination analysis with the first conjunct agreement.

Munn then considers examples of conjoined subjects where the conjuncts differ in number, the first conjunct being plural and the second singular. The analysis which assumes phrasal coordination predicts that the first conjunct agreement will license plural agreement on the verb, and elements such as sawa 'together' will be also licensed. Assuming clausal coordination, the presence of a singular second conjunct would inevitably rule out the structure, because the second clause does not contain the plural subject, and clausal analysis assumes that each conjunct is the subject of a separate clause.

Munn points out that another way to demonstrate that the first conjunct agreement is not clausal is to offer examples with elements that require semantic plurality to be licensed but do not require syntactic plurality. Such lexical items are same and different. If the first conjunct agreement is clausal, then it should be impossible with such elements. On the other hand, if it is phrasal, then such elements should be licensed. Munn gives grammatical examples with semantic plurality which is sufficient to license the lexical item nefs 'same'.

Munn points out that similar examples contain predicates that are necessarily group forming but do not contain an overt plural. For example, the predicate 'form a circle around the tree' requires a semantic plural to be licensed. He also points out that there is another kind of examples that do not depend on plurality but the syntactic constituency of the conjoined elements. He claims that one of the arguments for a hierarchical structure of coordinated phrases is the fact that a quantifier in the first conjunct can bind a pronoun in the second conjunct. This is expected if the first conjunct c-commands the second conjunct. On the other hand, if the first conjunct agreement has a clausal source, then it should be impossible with a quantificational first conjunct and a bound pronoun in the second conjunct. The fact that the bound pronoun interpretation is possible in such sentences shows that the two conjuncts are in the same clause. Therefore, the phrasal conjunction analysis, in which two 
conjuncts form a constituent, can account for this. The detailed analysis is provided in Section 5.

\section{Experiment design}

To disprove that linear postverbal agreement is a result of clausal ellipsis, we conducted a sentence-picture matching experiment. The experiment was administered using the online software Ibex (Drummond 2011). The participants' judgment responses were automatically recorded by Ibex and were subject to a statistical analysis afterward. Reaction times and response latencies were statistically analyzed and compared to judgment responses.

There were 30 participants, native speakers of BCS. They were third-year students at the University of Sarajevo and their mean age was 21 . They finished secondary school in Sarajevo or the surrounding area. The experiment was administered in parallel and there were two experimental sessions. At the beginning of the experiment, the biographic questionnaire and the consent form were administered offline. The biographic data were coded afterward.

The experiment took place in a phonetic laboratory that is relatively isolated from external sounds. All experimental conditions in the room were the same for both groups of participants. The participants would read a sentence for themselves and see a picture illustrating that sentence. They were instructed to rate to what degree the picture matches the sentence presented on the screen by using the mouse to click on the left or right side of the scrollbar. The left side was red and meant that the correspondence between the picture and the sentence was low and the right side of the scroll bar was green and meant high correspondence between the picture and the sentence. At the end of the experiment, the participants were given an impression sheet to express their opinion on the clarity and complexity of the task. The experiment did not exceed 25 minutes.

After eight practice examples, the actual experiment would start. There were 64 items for every participant. There were two seconds between every pair of a sentence and a picture. The sentencelength was balanced and the mean of the sentence length was 41 characters. A 2x2 factorial design was used. The stimuliwere designed so that four conditions involved collective predicates with CCA agreement and four involved non-collective predicates with CCA agreement. All agreement forms were either feminine or neuter. There were no (default) masculine agreement forms. There was a verb-subject (VS) order in every experimental item and each sentence would start with an adverbial phrase (AdvP) or a prepositional phrase (PP).

As explained above, collective predicates were chosen because they elicit agreement with the linearly closest conjunct, and yet, semantically, they have to be predicated from the entire conjunct. Four conditions involved coordinated mixed gender NPs (FN, NF) and four involved simple non-masculine NPs (F, N). Overall, there were eight conditions, each of which was present in four items yielding 32 
stimuli in total. We used plural forms of concrete nouns and inanimate and nonhuman nouns.

One group of stimuli involved a collective predicate and an $\mathrm{F}+\mathrm{N}$ conjunct, as in:

(1) Nagomilu su bile izdvojene prepone $i$ kladiva. on heap AUX were singled.out hurdles $_{F}$ and hammers $_{N}$ 'Hurdles and hammers were singled out on a heap.'

Another group involved a collective predicate and an $\mathrm{N}+\mathrm{F}$ conjunct, as in (2):

(2) Namostu su se mimoilazila vozila i kočije. on bridge AUX PRT passing vehicles $_{N}$ and carriages $_{F}$ 'Vehicles and carriages passed each other on the bridge.'

In eight stimuli, collective predicates were matched with simple non-masculine NPs, as in (3) and (4):

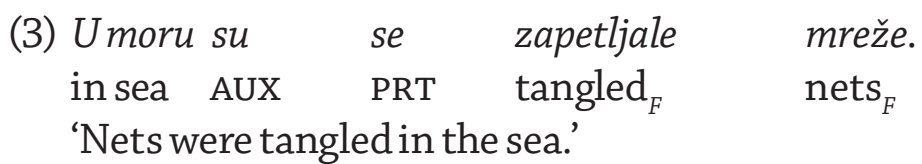

(4) Ubici su se sudarala koplja. in battle AUX PRT collided $_{N} \quad$ spears $_{N}$ 'Spears collided in the battle.'

The rest of the stimuli involved non-collective predicates. The subject structure was the same as for collective predicates. Subjects were $\mathrm{F}+\mathrm{N}$ conjuncts, as in (5), and $\mathrm{N}+\mathrm{F}$ conjuncts, as (6)

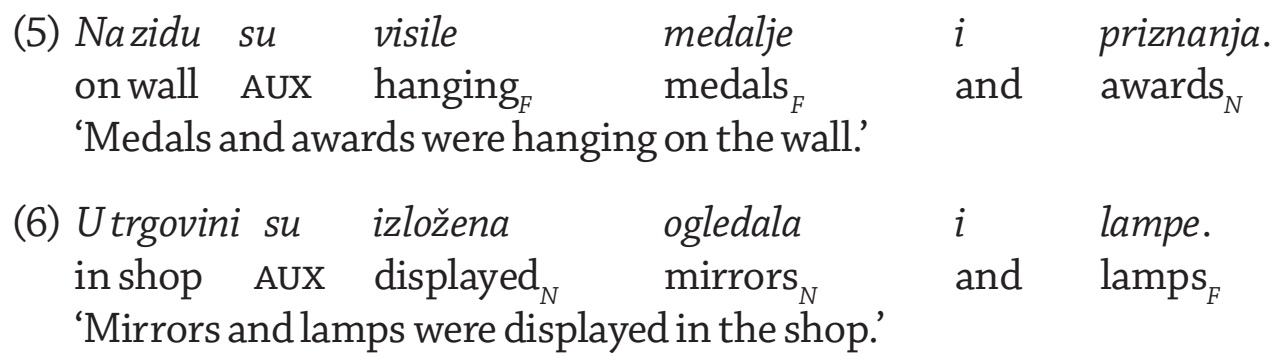

In eight stimuli, non-collective predicates were matched with simple nonmasculine NPs, as in (7) and (8):
(7) Uladicu su stavljene vizitke. in drawer AUX put visiting cards $_{F}$ 'Visiting cards were put in the drawer.'



(8) Nakonparade su počišćena parkirališta. afterparade AUX cleaned $_{N} \quad$ parkinglots $_{N}$ 'Parking lots were cleaned after the parade.'

In the case of fillers, there were also four conditions with collective and four conditions with non-collective predicates that showed CCA. We had one condition with coordinated masculine NPs $(\mathrm{M}+\mathrm{M})$ and $\mathrm{CCA}$, as in (9), and three conditions with all gender forms and corresponding agreement on the verb, as in (10), (11), and (12). All four examples below involve collective predicates.
(9) Naprelazu su se sudarili vozovi $i$ autobusi. atcrossing AUX PRT collided ${ }_{M} \quad$ trains $_{M}$ and buses $_{M}$ 'Trains and buses collided at the crossing.'
(10) Jedanpored drugog su složeni kompjuteri. one next to another AUX stacked ${ }_{M}, \quad$ computers $_{M}$ 'Computers are stacked next to each other.'
(11) Krozbrda su se provlačile rijeke. throughhills AUX PRT wriggled $_{F}$ rivers $_{F}$ 'Rivers wriggled through the hills.'
(12) Potocima su povezana jezera. brooks AUX connected ${ }_{N}$ lakes $_{N}$ 'Lakes are connected by brooks.'

The following examples are parallel to those in (9)-(12), but with non-collective predicates:

(13) Odzime su se smrzli prsti $i$ nokti. fromcold AUX PRT froze $_{M}$ fingers $_{M}$ and nails ${ }_{M}$ 'Fingers and nails froze because of the cold.'

(14) Nastolu su stajali telefoni. on table AUX placed $_{M}$ phones $_{M}$ 'Phones were placed on the table.'

(15) Napolici su stajale knjige. on shelf AUX placed $_{F}$ books $_{F}$ 'Books were placed on the shelf.'

(16) Učamcu su ostavljena vesla. in boat AUX left ${ }_{N} \quad$ paddles $_{N}$ 'Paddles are left in the boat.' 
Again, there were eight conditions and there were four items for every condition which resulted in 32 fillers. Half of the fillers were designed to exemplify sentence-picture mismatches. All 64 experimental items were randomized for each participant.

\section{Results}

Overall, examples with collective predicates and both types of subjects - conjoined \&P and simple NP subjects - show very high ratings in the sentence-picture matching task. The mean value of matchedness for collective predicates and both types of subjects was $76.7 \%$.

For collective predicates with feminine and neuter $(\mathrm{F}+\mathrm{N})$ subject conjuncts that show CCA, the matchedness between the picture and the sentence was $82 \%$. In examples with the same conditions but with the reversed order of conjuncts $(\mathrm{N}+\mathrm{F})$, the correspondence was somewhat lower $-71 \%$. There was a similar pattern for examples with collective predicates and simple NP subjects. In cases of neuter NPs and neuter agreement, the correspondence was again significantly lower (67\%) than with feminine NPs and CCA, where we had an $87 \%$ match. These results are summarized in the chart below.

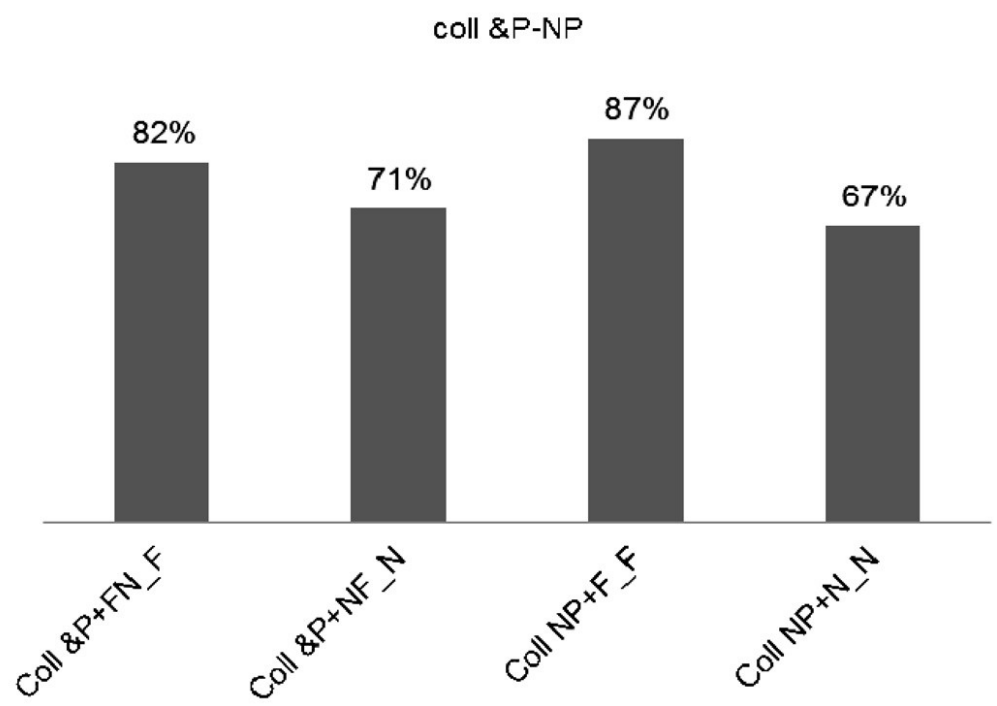

With non-collective predicates, the correspondence between sentences and pictures was extremely high (94\%), the subject being $\mathrm{F}+\mathrm{N}$ conjunct. The examples with simple feminine subject NPs also showed a high match -95\%. The examples with non-collective predicates and conjoined $\mathrm{N}+\mathrm{F}$ subjects or simple neuter NP subjects displayed $86 \%$ and $89 \%$ correspondence, respectively, as can be seen from the following graph. 
non-coll \&P-NP

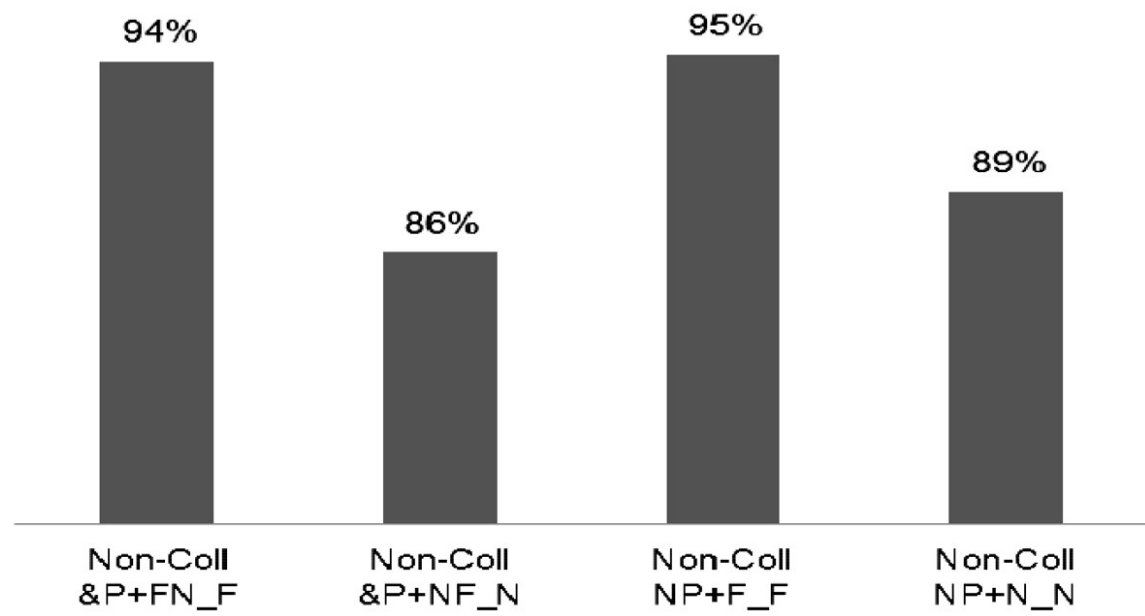

Regarding the analysis of fillers, for examples with single plural M, F, or $\mathrm{N}$ nouns that all exemplified a sentence-picture match, the correspondence between the sentence and the picture was rated $89 \%$ (mean). Examples with coordinated masculine conjuncts and masculine agreement, which were also designed to exemplify a sentence-picture match, were rated slightly higher $-90 \%$.

The rest of the fillers exemplified a sentence-picture mismatch. Examples with plural M, F and N nouns eliciting appropriate plural agreement on the verb were accompanied by the pictures displaying the same event depicted by the sentence but onlyin the singular form, as in (17):

(17) Nanebu su vijugali avioni.

on sky AUX meandered ${ }_{M}$ planes $_{M}$ 'Planes meandered in the sky.'

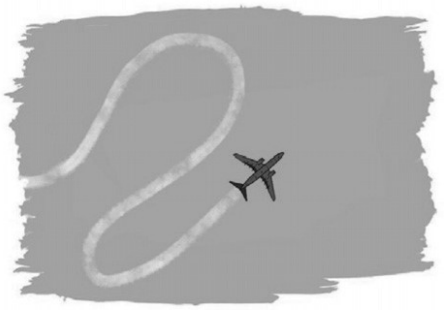

For all three genders, the mean value of the correspondence was $26 \%$. Examples with coordinated masculine conjuncts exemplifying singular agreement represent a curious case, as in (18):

(18) Naprelazu su se sudarili vozovi i autobusi. oncrossing AUX PRT collided trains $_{M}$ and buses $_{M}$ 'Trains and buses collided at the crossing.' 


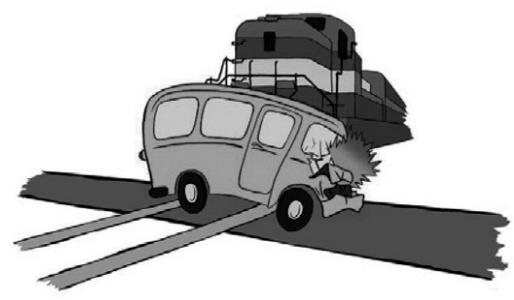

The correspondence was almost doubled in comparison with the singular nouns $-45 \%$. The results for the singular mismatch are illustrated in the graph below.

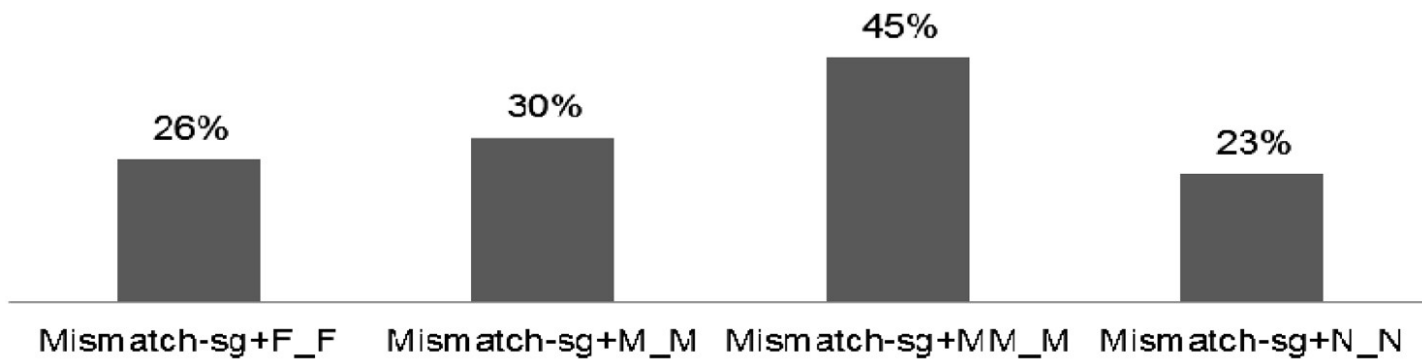

Several examples with plural feminine or masculine nouns and appropriate agreement on the verb were constructed to display an object mismatch, i.e. the picture was depicting a different item than the one in the example, as in (19) and (20):

(19) Jedan pored drugog su složeni kompjuteri. nextto each other AUX stored ${ }_{M}$ computers $_{M}$ 'Computers are stored next to each other.'

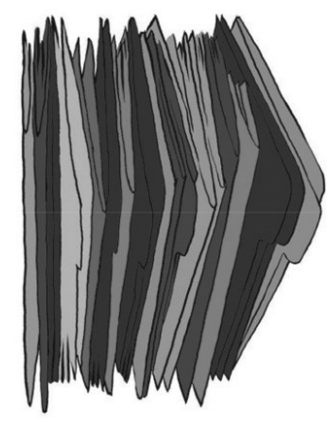

(20) Napolici su stajale knjige. on shelf AUX stood $_{F}$ books $_{F}$ 'The books stood on the shelf.'

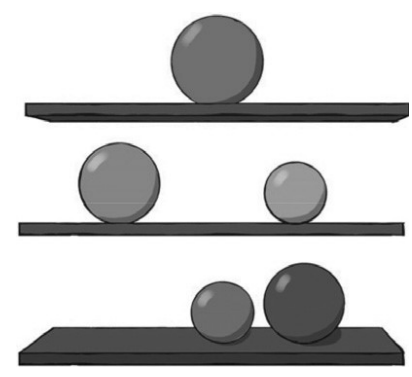


These examples were rated very low and the correspondence was 3\% for feminine nouns and $5 \%$ for masculine nouns. Adding another conjunct $(\mathrm{M}+\mathrm{M})$ significantly increased the scores. For the examples with conjoined masculine nouns where one item was appropriately illustrated in the picture whereas the other was a mismatch, the correspondence was $41 \%$.

\section{Mismatch_Object}

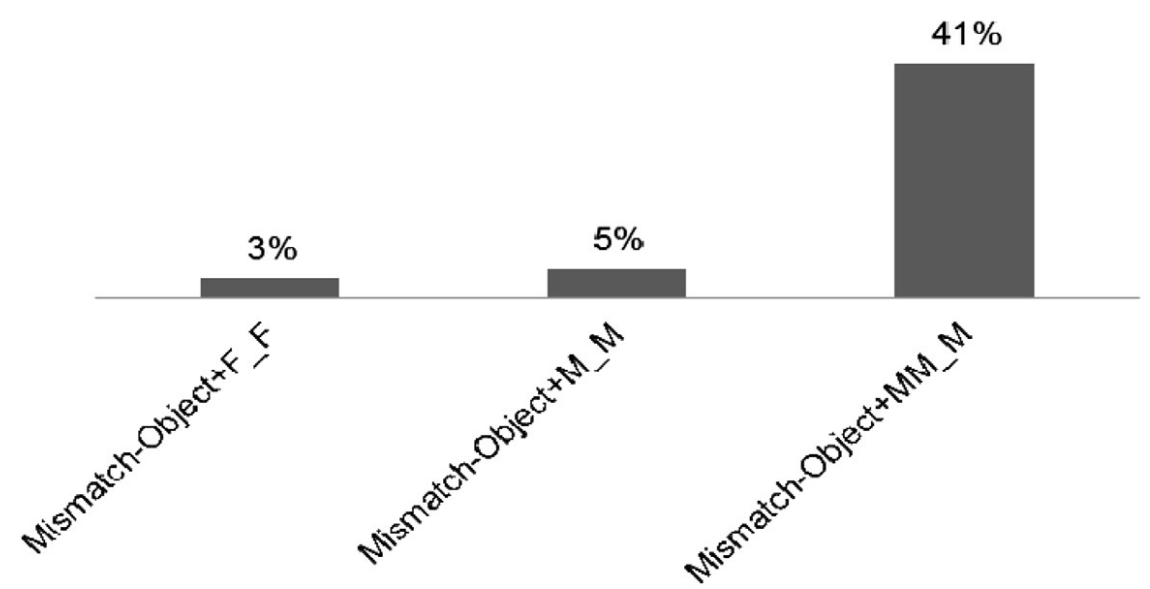

There were examples with plural masculine, feminine or neuter nouns and proper inflection on the verb, but the relevant adverbial or prepositional phrase was misrepresented in the image, as in (21), (22), and (23):

$\begin{array}{cllll}\text { (21) } \begin{array}{l}\text { Nafrižideru } \\ \text { on fridge }\end{array} & \text { su } & \text { se } & \text { sušile } & \text { kobasice. } \\ \text { dry }_{F} & \text { PRT } & \text { sausages }_{F}\end{array}$ 'Sausages were drying on the fridge.'

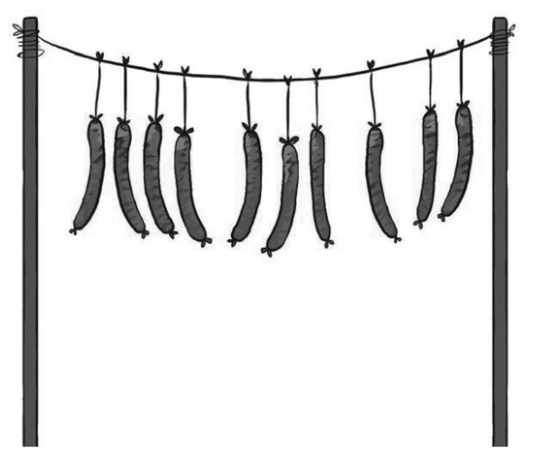

(22) Jedan nasuprot drugog su se parkirali kamioni. one opposite another AUX PRT parked trucks $_{M}$ 'Trucks were parked opposite each other.'

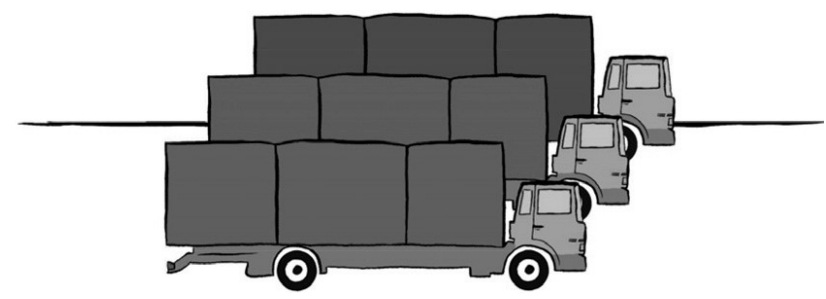


(23) Krozključaonicu su se vidjela sazviježđa. throughkeyhole AUX PRT see $_{N}$ constellations $_{N}$ 'Constellations could be seen through a keyhole.'

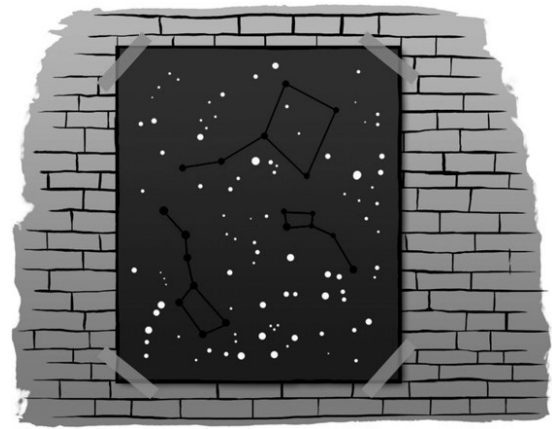

The correspondence was the lowest (15\%) with feminine nouns, whereas for neuter nouns it was $24 \%$ and for masculine $29 \%$, as can be seen in the graph below.

$$
\text { Mismatch_PP }
$$

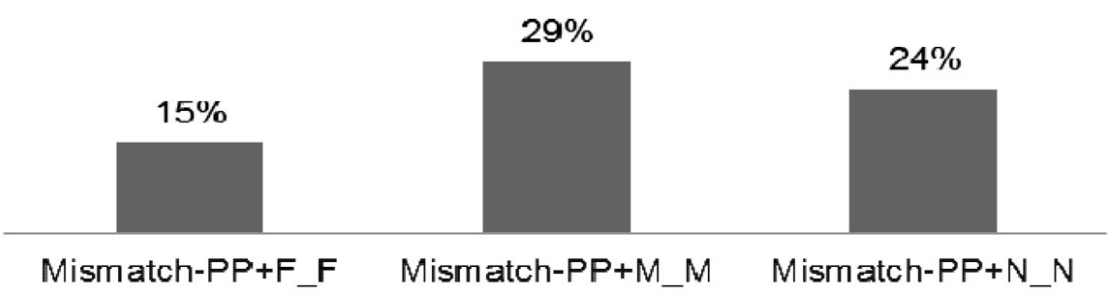

\section{Discussion}

The results seem to confirm the claim that the cases showing CCA are not a result of clausal ellipsis. To provide an appropriate context and test this claim, we designed examples with collective predicates since they unambiguously show whether the two event semantics is preserved or not. Our results showed that it is. The mean value of matchedness for collective predicates and both types of subjects was $76.7 \%$. More specifically, collective predicates with simple feminine NPs showed the highest matchedness (87\%), followed by $\mathrm{F}+\mathrm{N}$ conjuncts $(82 \%)$. The lowest matchedness occurred in examples with simple neuter NPs (67\%). Non-collective predicates manifest the same pattern - the matchedness increasing if the subject is feminine. For collective predicates and feminine NPs, the correspondence was $95 \%$ and for $\mathrm{F}+\mathrm{N}$ conjuncts $94 \%$. Figures drop significantly for neuter NPs (89\%) and $\mathrm{N}+\mathrm{F}$ conjuncts $(86 \%)$.

These results have additional implications. Why does the matchedness percentage increase when the subject is either a feminine NP or a conjoined NP with the closest conjunct being feminine? Perhaps one should consider the frequency of feminine gender in the language compared to the neuter. Data on the gender 
structure of the nominal corpus in BCS extracted from Web corpora of Bosnian, Croatian and Serbian ${ }^{12}$ show that in BCS, $40 \%$ of nominal lexicon consists of feminine nouns and only $14 \%$ neuter nouns. Interestingly, data from another Slavic language - Russian show almost identical ratio. Akhutina et al. (1999) show that in Russian, $41 \%$ of the nominal lexicon consists of feminine nouns and only $13 \%$ neuter nouns. Therefore, we might conclude that we are witnessing the frequency effect on comprehension in this instance.

The analysis of fillers also brings an interesting twist. The examples that were designed to show a sentence-picture match had high figures of correspondence as expected, the mean value was $89 \%$. For number and object mismatch, in the case of simple NP subjects, the figures were low as expected. For number mismatch, the average value was $28 \%$ and for object mismatch $4 \%$. However, in the case of coordinated masculine conjuncts, there was a significant rise in percentages. For the number mismatch, the matchedness was $45 \%$, although the conjuncts were plural and the picture showed a single object. For object mismatch, the correspondence was $41 \%$, even though one conjunct was misrepresented in the picture. What are the implications of this for the hypothesis of CCA not being the result of ellipsis?

On the one hand, it refutes the idea that we might be talking about ellipsis for CCA cases because had that been the case, all the examples with $\mathrm{M}+\mathrm{M}$ conjuncts and number and object mismatch would have been rated radically lower.

(24) Naprelazu su se sudarili vozovi i autobusi. oncrossing AUX PRT collided trains $_{M}$ and buses $_{M}$ 'Trains and buses collided at the crossing.'

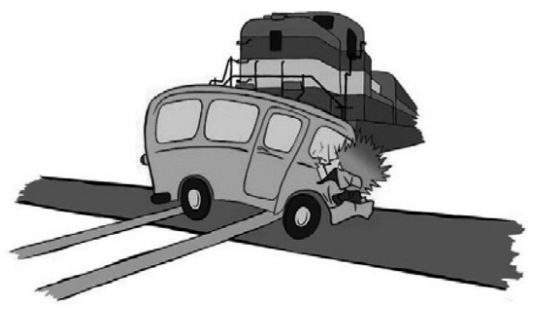

The percentage of $45 \%$ for matchedness between the sentence in (24) and the picture above shows that even with number mismatch, the experiment participants treated the participle form sudarili 'collided' as CCA because a train and a bus collided in the picture, not a train and a train, and a bus and a bus, as would be the interpretation if we were talking about clausal ellipsis.

However, $41 \%$ matchedness for $\mathrm{M}+\mathrm{M}$ conjuncts exemplifying an object mismatch points to something different. If we assume that the participial agreement is

12 Natural Language Processing group at the University of Zagreb compiled web corpora of Bosnian, Croatian and Serbian containing 429 million, 1,9 billion, and 894 million tokens, respectively. We are grateful to Nives Mikelic Preradovic, the head of NLP group, for her help in providing the data on the gender structure of nominal corpora. 
a clausal ellipsis, then that could explain why the matchedness was relatively high for the examples like the one in (25):

(25) Ukolicima su dovezeni kaktusi i kokosi. in trolley AUX brought ${ }_{M}$ cacti $_{M}$ and coconuts $_{M}$ 'Cacti and coconuts were brought in the trolley.'

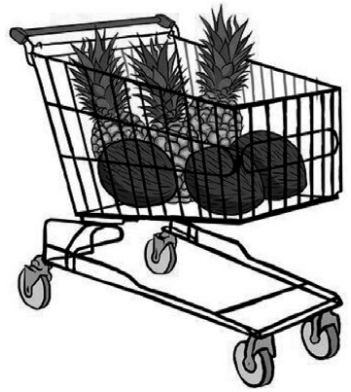

The clausal interpretation would assume that the cacti and coconuts were brought separately in different trolleys, so that could easily explain why the correspondence was $41 \%$. Coconuts were represented in the image and the fact that the other items were pineapples and not cacti does not bear much importance under clausal ellipsis interpretation because cacti would not have been expected to be in the trolley together with the coconuts in the first place.

However, this result is hardly significant in the context of the overall analysis. Only two experimental items exemplified this condition out of the 64 items in total. Also, if individual responses for every participant are analyzed, out of 30 participants there were only two who marked the matchedness to be very high for $\mathrm{M}+\mathrm{M}$ object mismatch and this affected the overall results. All the other participants opted for either the middle of the scale, meaning the matchedness was partial or the left end of the scale, indicating that the matchedness was very low. Further testing would be necessary to claim that the results for these two experimental items point at CCA being a case of ellipsis.

Furthermore, the analysis of experimental stimuli showed that the matchedness between the sentences and the pictures designed to illustrate CCA was very high so that it excluded the possibility of CCA being a case of clausal ellipsis. The analysis of fillers also confirmed this. Particularly interesting were the examples that show sentence-picture mismatch. Number mismatch showed that even though the number was violated as the pictures exemplified single objects and the conjuncts were plural, the participants still interpreted sentences as a case of coordination and CCA, rather than ellipsis. Therefore, we argue that the results of all other experimental items for all other conditions indeed point to CCA being a separate agreement strategy and that the cases with CCA cannot be interpreted as clausal ellipsis.

We paid special attention to the items containing collective predicates because their meaning has to be predicated from the entire conjunct. We hypothesized that if CCA is a case of ellipsis, then the matchedness for the examples with collective 
predicates would not be very high because the examples such as (26) would be interpreted as cars passing cars and carriages passing carriages and not as cars and carriages passing each other.

$$
\begin{aligned}
& \text { (26) Namostu su se mimoilazila } \begin{array}{llll}
\text { vozila } i & \text { kočije. } \\
\text { on bridge AUX PRT passing } & \text { vehicles } & \text { and } & \text { carriages } \\
F
\end{array} \\
& \text { 'Vehicles and carriages passed each other on the bridge.' }
\end{aligned}
$$

This did not happen. The matchedness was very high $-71 \%$ for $\mathrm{N}+\mathrm{F}$ conjuncts as in the example above. Therefore, we conclude that CCA is a legitimate agreement strategy.

\section{References}

Akhutina, Tatiana, Andrei Kurgansky, Maria Polinsky and Elizabeth Bates (1999). Processing of grammatical gender in a three-gender system: Experimental evidence from Russian. Journal of psycholinguistic research 28(6): 695-713, https://doi.org/10.1023/A:1023225129058

Aoun, Joseph, Elabbas Benmamoun and Dominique Sportiche (1994). Agreement, word order, and conjunction in some varieties of Arabic. Linguistic inquiry 25: 195-220

Aoun, Joseph, Elabbas Benmamoun and Dominique Sportiche (1999). Further remarks on first conjunct agreement. Linguistic inquiry 30: 669-681, https://doi.org/10.1162/002438999554255

Arsenijević, Boban, Jana Willer-Gold, Nadira Aljović, Nermina Čordalija, Marijana Kresić, Nedžad Leko, Frane Malenica, Lanko Marušič, Tanja Milićev, Nataša Milićević, Petra Mišmaš, Ivana Mitić, Anita Peti-Stantić, Branimir Stanković, Jelena Tušek and Andrew Nevins (2020). Elided Clausal Conjunction Is Not the Only Source of ClosestConjunct Agreement: A Picture-Matching Study. Syntax 23 (1): 78-104, https://doi.org/10.1111/synt.12171

Badecker, William (2007). A feature principle for partial agreement. Lingua 117: 15411565, https://doi.org/10.1016/j.lingua.2006.06.006

Benmamoun, Elabbas (1992). Functional and inflectional morphology: Problems of projection, representation and derivation. Doctoral dissertation. University of Southern California

Benmamoun, Elabbas, Archna Bhatia and Maria Polinsky (2010). Closest conjunct agreement in head final languages. Van Craenenbroeck, Jeroen, eds. Linguistic variation yearbook. Amsterdam: John Benjamins, 67-88, https://doi.org/10.1075/livy.10

Bhatt, Rajesh and Martin Walkow (2013). Locating agreement in grammar: An argument from agreement in conjunctions. Natural language and linguistic theory 31(4): 9511013, http://doi.org/10.1007/s11049-013-9203-y

Bock, Kathryn and Carol Miller (1991). Broken agreement. Cognitive psychology 23: 45-93, https://doi.org/10.1016/0010-0285(91)90003-7

Bošković, Željko (2009). Unifying first and last conjunct agreement. Natural language and linguistic theory 27: 455-496, http://doi.org/10.1007/s11049-009-9072-6 
Bošković, Željko (2010). Conjunct-sensitive agreement: Serbo-Croatian vs Russian. Zybatow, G., P. Dudchuk, S. Minor and E. Pschehotskaya, eds. Proceedings of FDSL 7. Frankfurt am Main: Peter Lang, 31-48

Chomsky, Noam (2013). Problems of projection. Lingua 130: 33-49, https://doi.org/10.1016/j.lingua.2012.12.003

Corbett, Greville (1983a). Hierarchies, targets, and controllers: Agreement patterns in Slavic. London: Croom Helm, https://doi.org/10.2307/414173

Corbett, Greville (1983b). Resolution rules: Agreement in person, number and gender. Gazdar, G., E. Klein and G. Pullum, eds. Order, concord and constituency. Dordrecht: Foris, 175-214, http://doi.org/10.1515/9783110876734

Corbett, Greville (1991). Gender. Cambridge: Cambridge University Press, https://doi.org/10.1017/CBO9781139166119

Čordalija, Nermina, Amra Bešić, Ivana Jovović, Nevenka Marijanović, Lidija Perković, Midhat Šaljić, Dženana Telalagić and Nedžad Leko (2016). Grammars of participle agreement with conjoined subjects in Bosnian/Croatian/Serbian. Journal of Slavic linguistics 24 (1): 71-112, http://doi.org/10.1353/jsl.2016.0007

Doron, Edit (2000). VSO and left-conjunct agreement: Biblical Hebrew vs Modern Hebrew. Carnie, Andrew and Eithne Guilfoyle, eds. The syntax of verb initial languages. Oxford: Oxford University Press, 75-95

Drummond, Alex (2011). IbexFarm. Version 0.2.7. Available at: spellout.net/ibexfarm.

Franck, Julie (2011). Reaching agreement as a core syntactic process: Commentary on Bock and Middelton 'Reaching agreement'. Natural language and linguistic theory 29: 10711086, http://doi.org/10.1007/s11049-011-9153-1

Franck, Julie, Ulrich Frauenfelder and Luigi Rizzi (2007). A syntactic analysis of interference in subject-verb agreement. MIT Working papers in linguistics 53: 173-190

Franck, Julie, Glenda Lassi, Ulrich Frauenfelder and Luigi Rizzi (2006). Agreement and movement: A syntactic analysis of attraction. Cognition 101: 173-216, https://doi.org/10.1016/j.cognition.2005.10.003

Franks, Steven and Jana Willer-Gold (2014). Agreement strategies with conjoined subjects in Croatian. Witkos, Jacek and Sylwester Jaworski, eds. New insights into Slavic linguistics. Frankfurt am Main: Peter Lang, 91-115, https://doi.org/103726/978-3-653-04359-4

Marušič, Franc, Andrew Nevins and Amanda Saksida (2007). Last-conjunct agreement in Slovenian. Compton, Robert, Magda Goledzinowska and Ulyana Savchenko, eds. Formal approaches to Slavic linguistics 15: The Toronto meeting. Ann Arbor: Michigan Slavic Publications, 210-227

Marušič, Franc, Andrew Nevins and William Badecker (2015). The grammars of conjunction agreement in Slovenian. Syntax 18(1):39-77, https://doi.org/10.1111/synt.12025

Mitrović, Moreno (2014). Morphosyntactic atom of propositional logic. Doctoral dissertation. University of Cambridge

Mitrović, Moreno and Uli Sauerland (2014). Decomposing coordination. Iyer, J. and L. Kusmer, eds. Proceedings of NELS 44. Amherst: GLSA, University of Massachusetts, 39-52 
Mitrović, Moreno and Uli Sauerland (2016). Two conjunctions are better than one. Acta Linguistica Hungarica 63.4: 471-494, http://doi.org/10.1556/064.2016.63.4.5

Munn, Alan (1992). A null operator analysis of ATB gaps. The linguistic review 9: 1-26, http://doi.org/10.1515/tlir.1992.9.1.1

Munn, Alan (1999). First conjunct agreement: Against a clausal analysis. Linguistic inquiry 30(4): 643-68, https://doi.org/10.1162/002438999554246

Nevins, Andrew (2016). Discarding a clausal coordination and ellipsis source for CCA: a picture-matching study. Paper presented at Ellipsis across borders conference, Sarajevo, 20-21 June 2016

Puškar, Zorica and Andrew Murphy (2015). Closest conjunct agreement in Serbo-Croatian: A rule-ordering account. Assmann, A., S. Bank, D. Georgi, T. Klein, P. Weisser and E. Zimmermann, eds. Topics at Infl. Leipzig: Institut fur Linguistic der Universität Leipzig, [Linguistische Arbeitsberichte (LAB), 92], 441-482

Schein, Barry (2017). 'And': Conjunction Reduction Redux. Cambridge, MA: The MIT Press.

Willer-Gold, Jana et al. (2016). Conjunct agreement and gender in South Slavic: From theory to experiments to theory. Journal of Slavic Linguistics 24(1): 187-224, http://doi.org/10.1353/jsl.2016.0003

\section{Slaganje s bližom imenicom u koordiniranom postverbalnom subjektu u bosanskom/hrvatskom/srpskomjeziku: eksperimentalna studija}

U nekim ranijim radovima o strategijama slaganja predikata s koordiniranim subjektom (vidi Marušič et al. 2015, Willer-Gold et al. 2016, Čordalija et al. 2016), ustanovljeno je da slaganje predikata s bližom imenicom ukoordiniranom subjektujestjedina moguća strategija slaganja kada subjekt slijediiza predikata. Međutim, primjerizakoje se tvrdi da su rezultat slaganja predikatas bližom imenicom u takvim kontekstima mogli bi se potencijalno analizirati i kao rezultat rečenične elipse. Upravo takvu analizu zagovaraju Aoun, Benmamoun i Sportiche (1994). Njihov pristup se zasniva na primjerima iz triju dijalekata arapskog jezika te utvrđuju da je linearno slaganje u kontekstima s postverbalnim subjektom rezultat rečenične elipse, a ne slaganja predikata $s$ bližom imenicom. Prema tome, oni predviđaju semantičku nezavisnost dva koordinirana događaja. Međutim, Munn (1999) ukazuje kako je ovu tvrdnju teško obraniti ako se uzme u obzir specifičan tip predikata, tzv. zbirni predikat. Zbog toga smo dizajnirali eksperiment u kojem smo tražili od izvornih govornika bosanskog/hrvatskog/srpskog jezika da ocijene u kolikoj mjeri rečenice sa zbirnim glagolima koje prethode koordiniranom subjektu odgovaraju pratećem crtežu koji predstavlja događaj ili situaciju koju rečenica izražava. Rezultati eksperimenta pokazuju da primjeri slaganja predikata $s$ koordiniranim subjektom nisu rezultat rečenične elipse, već zasebna strategija slaganja - slaganje $s$ bližom imenicom. Budući da eksperiment nije pokazao značajnu razliku u prihvatljivosti između rečenica koje sadržavaju koordinirani subjekt i prosti nekoordinirani subjekt sa zbirnim glagolima, zaključili smo da rečenice s koordiniranim subjektom i zbirnim predikatom (glagoli poput sudaratise) nisu derivirani pomoću rečenične elipse. U protivnom, takve rečenice bile bi rangirane po prihvatljivosti znatno niže od svih drugih zbog toga što bi crtež koji ide uz takve rečenice bio nekompatibilan s interpretacijom koja podrazumijeva dva događaja. Takva interpretacija bila bi neizbježna ukoliko bi se takve rečenice u dubinskoj strukturi sastojale od dviju koordiniranih rečenica.

Keywords: predicate agreement, postverbal subjects, collective predicates, coordinated subjects, syntax, Slavic languages

Ključne riječi: slaganje predikata, postverbalni subjekt, zbirni predikat, koordinirani subjekt, sintaksa, južnoslavenski jezici 